\title{
Perioperative Utilization of Internal Iliac Artery Balloons, Does it really help in Case of Abnormal Placental Invasion?
}

\author{
Georgios Androutsopoulos* and Georgios Decavalas \\ Department of Obstetrics and Gynecology, University of Patras, Medical School, Greece
}

Submission: May 14, 2017; Published: May 24, 2017

*Corresponding author: Georgios Androutsopoulos, Assistant Professor, Department of Obstetrics and Gynecology, University of Patras, Medical School, Rion 26504, Greece, Tel: +306974088092; E-mail: androutsopoulos@upatras.gr; androutsopoulosgeorgios@hotmail.com

\section{Editorial}

The abnormal placental invasion is characterized by partial or complete abnormal adherence of the placenta to the underlying uterine wall (accreta, increta and percreta) [1,2]. It is correlated with significant morbidity and mortality for both mother and fetus, mainly because of the severe peripartum bleeding and preterm birth [3,4]. Maternal mortality is almost $7 \%$, despite optimal planning and surgical management $[4,5]$. Recent years, some people claim that perioperative use of internal iliac artery balloons may be helpful in patients with abnormal placental invasion [5,6]. However, the utilization of this technique represents an area of ongoing debate, mainly because its efficacy still remains unproven $[5,6]$.

The technique of internal iliac artery balloons in patients with abnormal placental invasion, was first described in 1997 by Dubois [7]. On the day of delivery, balloon catheters are placed in both internal iliac arteries using Seldinger technique, via the transcutaneous common femoral artery approach and under fluoroscopic guidance [6-10]. The proper positioning of the balloon catheters and the effective vascular occlusion are angiographically confirmed [6-10]. Subsequently, patient is taken directly to the operating theatre for caesarean section [610].

After the delivery of fetus and clamping umbilical cord, internal iliac artery balloons are inflated according to the surgeon's discretion and the timing of inflation is recorded $[6,10]$. The technique causes only temporary relief in intraoperative pelvic bleeding, mainly because of the fact that major anastomotic routes in the female pelvis will function soon after balloon inflation [6,8-15]. In most cases, balloon inflation could significantly reduce pelvic blood supply, although complete cessation is quite difficult $[9-11,13,14]$. However, in some cases there is adequate blood perfusion only a few $\mathrm{cm}$ lower to the inflated balloons $[9-11,13,14]$.
Based on the above mentioned, internal iliac artery balloons should be inflated only with the onset of severe and uncontrolled pelvic bleeding [6,9-15]. In this way, we minimize local blood supply and control dramatic blood loss by using the technique only when it is absolutely necessary [6,9-15]. Moreover, we avoid the development of additional anastomotic channels in the female pelvis by using the method appropriately [6,9-15]. There are many advantages regarding the use of internal iliac artery balloons in cases with abnormal placental invasion $[10,14]$. The most important of them, is the significant reduction of intraoperative blood loss $[9,10,14]$. In this way, we avoid uncontrolled and life threatening situations during a caesarian section complicated with abnormal placental invasion $[10,14]$. Moreover, there is an essential reduction in overall transfusion requirements over the perioperative period $[9,10,14]$. Furthermore, there is a better visualization of the surgical field during operation, which helps surgeon to recognize anatomical structures and minimize surgical complications $[9,10,14,16]$.

The main limitation in this technique, is the fact that female pelvis has an extended vascular network with multiple anastomoses [8,9,11,13-15]. However, we could easily overcome this limitation, by inflating internal iliac artery balloons only when it is absolutely necessary $[9,11,13-15]$. Based on data published on case reports and larger series, there are some complications related with the utilization of internal iliac artery balloons [6,8,14]. The development of these complications usually depends on operator's experience, used technique, available equipment and patient's characteristics [6]. Although it is very difficult to estimate accurately, the overall complication rate usually varies between $6-16 \%[6,8,12,14]$.

Pulmonary embolism, thromboembolic events (5\%) and lower limb ischemia, represent some major complications [6,8,12,14,16-18]. Arterial spasm, hematoma, false aneurysm, 
nerve injury, allergy in radiographic contrast media and nephrotoxicity, represent some minor complications in patients treated with this technique [6,8,12,14,16-18]. Additionally, air in pressurized lines and symptomatic hypotension are some less common complications $[6,8,14,16-18]$. In conclusion, the utilization of internal iliac artery balloons is very helpful in cases of abnormal placental invasion $[9,10]$. In many cases caesarean hysterectomy could not be avoided, as the technique has only temporary effect on intraoperative blood loss $[9,14]$. Moreover, future studies are needed in order to investigate more accurately the efficacy of this approach in patients with abnormal placental invasion $[6,10,13]$.

\section{References}

1. Irving F, Hertig A (1937) A study of placenta accreta. Surg Gynecol Obstet 64: 178-200.

2. Khong $\mathrm{T}$ (2008) The pathology of placenta accreta, a worldwide epidemic. J Clin Pathol 61(12): 1243-1246.

3. Eshkoli T, Weintraub A, Sergienko R, Sheiner E (2013) Placenta accreta: risk factors, perinatal outcomes, and consequences for subsequent births. Am J Obstet Gynecol 208(3): 219 e1-7.

4. O’Brien J, Barton J, Donaldson E (1996) The management of placenta percreta: conservative and operative strategies. Am J Obstet Gynecol 175(6): 1632-1638.

5. ACOG (2012) Committee opinion no. 529: placenta accreta. Obstet Gynecol 120(1): 207-211.

6. Ballas J, Hull A, Saenz C, Warshak C, Roberts A, et al. (2012) Preoperative intravascular balloon catheters and surgical outcomes in pregnancies complicated by placenta accreta: a management paradox. Am J Obstet Gynecol 207(3): 216 e1-5.

7. Dubois J, Garel L, Grignon A, Lemay M, Leduc L (1997) Placenta percreta: balloon occlusion and embolization of the internal iliac arteries to reduce intraoperative blood losses. Am J Obstet Gynecol 176(3): 723-726.

8. Shrivastava V, Nageotte M, Major C, Haydon M, Wing D (2007) Casecontrol comparison of cesarean hysterectomy with and without prophylactic placement of intravascular balloon catheters for placenta accreta. Am J Obstet Gynecol 197(4): 402 e1-5.k

9. Carnevale F, Kondo M, de Oliveira Sousa W, Santos A, da Motta Leal Filho J, et al. (2011) Perioperative temporary occlusion of the internal iliac arteries as prophylaxis in cesarean section at risk of hemorrhage in placenta accreta. Cardiovasc Intervent Radiol 34(4): 758-764.

10. Androutsopoulos G, Decavalas G (2013) Perioperative internal iliac artery balloon occlusion in patients with abnormal placental invasion. J Community Med Health Edu 3(3): e117.

11. Chait A, Moltz A, Nelson J (1968) The collateral arterial circulation in the pelvis. An angiographic study. Am J Roentgenol Radium Ther Nucl Med 102(2): 392-400.

12. Kidney D, Nguyen A, Ahdoot D, Bickmore D, Deutsch L, et al. (2001) Prophylactic perioperative hypogastric artery balloon occlusion in abnormal placentation. AJR Am J Roentgenol 176(6): 1521-1524.

13. Clausen C, Stensballe J, Albrechtsen C, Hansen M, Lonn L, et al. (2013) Balloon occlusion of the internal iliac arteries in the multidisciplinary management of placenta percreta. Acta Obstet Gynecol Scand 92(4): 386-391.

14. Dilauro M, Dason S, Athreya S (2012) Prophylactic balloon occlusion of internal iliac arteries in women with placenta accreta: literature review and analysis. Clin Radiol 67(6): 515-520.

15. Levine A, Kuhlman K, Bonn J (1999) Placenta accreta: comparison of cases managed with and without pelvic artery balloon catheters. J Matern Fetal Med 8(4): 173-176.

16. Thon S, McLintic A, Wagner Y (2011) Prophylactic endovascular placement of internal iliac occlusion balloon catheters in parturients with placenta accreta: a retrospective case series. Int J Obstet Anesth 20(1): 64-70.

17. Mok M, Heidemann B, Dundas K, Gillespie I, Clark V (2008) Interventional radiology in women with suspected placenta accreta undergoing caesarean section. Int J Obstet Anesth 17(3): 255-261.

18. Greenberg J, Suliman A, Iranpour P, Angle N (2007) Prophylactic balloon occlusion of the internal iliac arteries to treat abnormal placentation: a cautionary case. Am J Obstet Gynecol 197(5): 470 e1-4.

\section{Your next submission with Juniper Publishers} will reach you the below assets

- Quality Editorial service

- Swift Peer Review

- Reprints availability

- E-prints Service

- Manuscript Podcast for convenient understanding

- Global attainment for your research

- Manuscript accessibility in different formats

( Pdf, E-pub, Full Text, Audio)

- Unceasing customer service

Track the below URL for one-step submission https://juniperpublishers.com/online-submission.php 